\title{
A Macro-level Error Analysis of Iranian Undergraduate EFL Learners' Performance on Writing Tasks
}

\author{
Mohammad Davoudi (Corresponding Author) \\ Assistant Professor of TEFL \\ Department of English Language and Literature \\ Hakim Sabzevari University, Iran \\ E-mail: davoudi2100@gmail.com
}

\begin{abstract}
Asghar Moulavi Nafchi
Hakim Sabzevari University, Iran

E-mail: a.moulavi.n@gmail.com
\end{abstract}

Senior Lecturer, Department of English Language and Literature

Omid Mallahi, Ph.D. Candidate of TEFL

Department of English Language and Literature, Hakim Sabzevari University, Iran

E-mail: mallahiomid68@gmail.com

Received: Sep. 10, 2015 Accepted: Nov. 16, 2015 Published: November 16, 2015

http://dx.doi.org/10.5296/jse.v5i4.8516 URL: http://dx.doi.org/10.5296/jse.v5i4.8516

\begin{abstract}
Writing in a foreign language is a highly complex activity and creating an accurate and fluent text demands the dedication of effort and acquisition of expertise in different aspects of writing. Many EFL students are not competent enough in this skill and it is natural to see some instances of errors and deficiencies in their written texts and it is expected that writing instructors be equipped with the essential knowledge and tools to respond to these problems. Accordingly, the present study incorporated insights from the practices of error analysis and the principles of feedback and effective written commentaries in examining a semester-long
\end{abstract}


corpus of a group of Iranian undergraduate EFL learners' written texts in a paragraph writing course. The study identified and analyzed the instances of errors in different aspects of writing (namely, content and organization, support and development, cohesion and coherence, structure, vocabulary and mechanics), and explored the instructor's feedback and written commentary on these aspects. The study introduces a flexible, analytic, comprehensive and context-sensitive feedback providing rubric to EFL writing.

Keywords: error analysis, feedback, EFL writing, writing rubric 


\section{Introduction}

Gaining competence in writing skill is not naturally acquired and this skill is usually learned by engaging in a set of instructional practices or through other linguistic and sociocultural experiences (Myles, 2002). It is considered as a rather complex skill which requires the orchestration of various cognitive, metacognitive and social strategies. Raimes (1983) identified the components of fluent and effective writing: content, writer's process, audience, purpose, word choice, organization, mechanics, grammar and syntax. The students who are writing in L2 in academic contexts must gain competence in the accurate and appropriate use of language, learn effective writing strategies and skills and put conscious effort and attempt informed practices in constructing texts, conveying their intended ideas and, hence, developing their writing ability. In spite of being a highly valued skill, most of the second/foreign language students face a lot of difficulties when asked to accurately and formally express, organize and develop their ideas in academic contexts.

Most of the students, based on their objectives in academic contexts and more specifically in writing classes, attempt to write in fluent language and create error-free texts. However, it is natural to see some flaws or deviations in the performance of learners who are writing in the languages they do not have enough competence in or are not completely familiar with the conventions of writing in them. Therefore, observing a variety of errors in the learners' linguistic production is natural and inevitable. Errors in writing are defined by Ferris (2011) as "morphological, syntactic, and lexical forms that deviate from rules of the target language, violating the expectations of literate adult native speakers" (p. 3). Considering the fact that foreign language learning is a gradual process and errors are expected on all levels of learning, Ferris (2002) indicates that conducting informative error analysis, which can identify the lacunae in the learners' linguistic knowledge and their needs, and, in subsequent procedures, application of systematic corrective techniques can enhance the effectiveness of the teaching and learning process.

In the last decades, teachers' feedback and the quality of their response to students' written materials have been considered as central issues for research in the area of writing. There has been a shift towards the developmental view of teacher feedback/response and its potential to improve students' learning and to help them achieve academic and professional literacy needed for participation in intellectual communities (Hyland, 2010). It is argued that to contribute to development in writing, feedback needs to have particular characteristics: it should allow the writer to see where his/her current position and knowledge relative to the intended quality performance is; what the key features of the desired performance are and what is needed to bridge the gap and achieve that intended quality performance (Parr \& Timpersely, 2010). However, it is believed that "for writing instructors, responding to student writing is a critical endeavor that is often fraught with frustration and uncertainty" (Ferris, 2014, p. 6).

In fact, due to teachers' workloads, providing feedback for all learners and on most of their drafts for all aspects of their performance may be a highly demanding task and fulfilling the objective of offering individualized attention and concern for improving the writing ability of 
all the learners can be a highly challenging endeavor. Therefore, coming up with effective ways that can, to the extent possible, reduce this burden and facilitate the feedback-providing process is highly justified. Using writing rubrics can be considered as one of these effective methods. In fact, using a systematic and comprehensive writing rubric, which is capable of informing the learners about their strengths and weaknesses and provide them with some meaningful scores and comments and suggestions for their revision and subsequent performances in writing the texts can be considered as an effective method. Accordingly, the present study attempts to operationalize the link between error analysis and feedback and, based on authentic performances and a semester-long corpus of writing practices and the instructor's commentary on a group of Iranian undergraduate EFL learners' written drafts, develop a comprehensive and context-sensitive writing rubric.

\section{Literature Review}

The present study draws on some areas of educational and cognitivere research and this section offers a theoretical overview of the main concepts operationalized in the study.

\subsection{Error Analysis}

Making errors is a natural part of language learning in any new language. Richards and Schmidt (2002) define an error as "the use of language in a way which a fluent or native speaker of the language regards as faulty or incomplete learning" (p.184). Due to the importance of the learners' systematic errors in accounting for and revealing some informative insights into the nature of learners' learning process, this aspect has received an extensive amount of attention and a large number of theoretical/empirical studies has been done in this regard (e.g., Brown, 2007; Corder, 1967, 1971; Gass \& Selinker, 2001; Krashen, 1982; Selinker, 1972). According to Dulay, Burt and Krashen (1982) studying learners' errors is performed with two main objectives in mind: (1) the data provided by such analyses can help us make some inferences about the nature of language learning process, and (2) it can inform the teachers, curriculum designers and materials development experts about the problematic areas in the learners' performance and specifies the error types which possibly prevent the learners from using language and communicating effectively which in turn requires rehabilitative endeavors and effective materials and instructional practices to resolve these deficiencies.

A variety of approaches and taxonomies are suggested for exploring and explaining the learners' errors (Dulay, Burt \& Krashen, 1982). In the error types based on linguistic category taxonomies, errors are classified in terms of specific language component (e.g., pronunciation, grammar, semantics, style and discourse) or the specific linguistic constituent (e.g., main/subordinate clause, phrases or different parts of speech) that is affected by error. In error types based on comparative taxonomy, the structure of L2 errors are compared with other certain types of constructions. This procedure is mostly conducted within the contrastive analysis tradition (Ellis \& Barkhuizen, 2005) which predicts the possible errors in the learners' performance by contrasting the linguistic systems of the two languages concerned. It is natural to see some instances of errors in the learners' performance on productive skills such as writing. Myles (2002) believes that since in L2 writing learners need 
more attempts in gaining, formulating and analyzing ideas, committing errors is natural and inevitable. Foreign language learners may face many problems in mechanical, grammatical, formal, organization and sociolinguistic aspects of the target language. Therefore, adopting a balanced and comprehensive approach which can target all these important aspects of students' performance, inform them about the problematic and erroneous areas, offer them systematic feedback and opportunities to resolve the problematic aspects of their written texts and, hence, improve their writing ability is a valuable endeavor.

\subsection{Significance of feedback in writing}

Larsen-Freeman (2003) defines feedback as evaluative information provided on the learners' linguistic performance. Providing feedback to students regarding their written performance is recognized as one of the most important tasks of L2 writing teachers because it offers a kind of individualized attention to the learners which is mostly impossible under normal classroom conditions (Hyland \& Hyland, 2006). Most approaches to second language writing pedagogy have specified a primary role for feedback practice, but research undertaken regarding the role of feedback in L2 writing classrooms has referred to the fact that "there are no simple [and conclusive] answers to questions such as which activities merit feedback, how and when to give feedback and what the benefits of giving feedback are" (Long \& Richards, 2006, p. xiii). However, it is generally accepted that feedback on students' written assignments can greatly help them to understand features of good writing. In fact, it is generally believed that the provision of appropriate feedback, which is effectively aligned with the instructional procedures and goals, can act as a scaffolding tool which help learners become more self-regulated and improve their writing (Bitchener \& Knoch, 2008; Chandler, 2003; Ferris, 2002; Lee, 2003; Myles, 2002).

Previous research on feedback had studied the purposes, processes and effects of feedback and its various features and facets like "degrees of explicitness (direct vs. indirect), timing (immediate vs. delayed), the manner of delivery (e.g., handwritten vs. delivered using technology), the source (self, the teacher, or peers), and even the visual presentation (i.e., the color of feedback)" (Elwood \& Bode, 2014, p. 334). There are several methods of providing feedback which can be effective in making the learners aware of their strengths and weaknesses and help them improve their writing. For example, in the case of written text, instructors can indicate on the margin of the text that a number of errors have occurred in a specific line or paragraph (Elwood \& Bode, 2014). They can also move a step forward and indicate the location of error by circling or underling it (Ferris \& Roberts, 2001) or showing its category and type by using specific codes (Kubota, 2001) which possibly reduces the cognitive loads, time and effort expended on the part of students to correct the errors. The instructors can also adopt more elaborate feedback procedures and provide learners with both score (in a holistic or analytic way) and some comments regarding their performance on different aspects of writing. In spite of being highly valuable in terms of being compressive, clear and effective, provision of such direct and detailed comments on individual papers is highly demanding and time-intensive for writing teachers and instructors (Chandler, 2003). Therefore, designing methods and developing instruments (such as writing rubrics) which 


\section{$\triangle 1$ Macrothink}

would possibly facilitate the practice of offering feedback to the learners and on their multiple written tasks can be a rewarding practice.

\subsection{Writing rubrics}

Rubric in educational literature is widely defined as a scoring tool which is capable of providing a qualitative appraisal of students' work. It is sensitive to the important dimensions of performance and the expected standards for reaching a high level of performance (Arter \& McTighe, 2001; Jonsson \& Svingby, 2007; Perlman, 2003). As for the effectiveness of rubrics in educational settings, Jonsson and Svingby (2007), after reviewing a total of 75 studies on the use of rubrics and their benefits in performance assessment, commented that such devices have advantages like "increased consistency of scoring, the possibility to facilitate valid judgment of complex competencies, and promotion of learning" (p. 130). Nowadays, classroom teachers and educators make use of rubrics to assess the performance of students in different aspects of language and skills such as writing.

Rezaei and Lovorn (2010) asserted that the dissatisfaction of teachers and administrators with traditional essay grading strategies, which mostly issued a subjective rather than objective assessment of the students' performance, led to the use of rubrics which are recognized as capable of providing a more objective measure of the students' performance on the written tasks. It could also give them more confidence about their assessment practices since such devices are considered more reliable and valid (Silvestri \& Oescher, 2006). Moreover, since writing is a complex process, it requires effective instruction and assessment and teachers must effectively and clearly express their expectations to the students with regard to the specific tasks they engage in (Sundeen, 2014). One of the ways whereby these expectations can be communicated is through the use of rubrics which should effectively address the specific writing elements and issues that the students must take into consideration while writing (Andrade, Du, \& Wang, 2008; Fang \& Wang, 2011).

The literature has also revealed some studies in the domain of writing which have made use of rubrics as part of their procedures or for assessment and feedback providing purposes. For example, Andrade (2001), working with a sample of 242 students in a quasi-experimental design, asked the students to write three essays and required the treatment group to explain the criteria their teachers have used in evaluating their writings and then to score their tasks using a rubric. The results indicated that the rubric had significant effect only on the scores of second essay and, therefore, it was suggested that providing and explaining a rubric to the learners can only improve their knowledge of criteria for writing and does not necessarily have an effect on their actual writing practice. In subsequent study on using rubrics for making essays, Andrade and Boulay (2003) with a sample of 397 ( $7^{\text {th }}$ and $8^{\text {th }}$ grades) students and in a quasi-experimental design compared the situations where both control and treatment groups wrote two essays and received a rubric; the treatment group also received two sessions of specific rubric training to self-assessed their performance. The results indicated no significant effect of training in rubric on the students' scores which was attributed to the insufficiency of intervention, the possible effects of rubric and school conditions. Moreover, Brown, Glasswell, and Harland (2004), in a descriptive study, used rubrics for argumentative 
writing. The study mainly focused on the effects of metacognitive training and modeling on the students' performance, but there was no explicit account of how the rubric was used in the intended intervention.

Andrade, Du and Wang (2008) and Andrade, Wang, Du and Akawi (2009) set other quasi-experimental studies in which a number of variables such as the effects of time used for writing, effect of prior knowledge of rubric, and students' self-efficacy were inspected along with the use of rubrics. Totally, the findings indicated no significant effect of time used and prior knowledge of rubrics on the students' essay scores and there was also no significant effect of short term use of rubrics on students' self-efficacy. In another quasi-experimental study on using writing rubrics, Andrade, Du and Mycek (2010) found that the students in the treatment group who were given a rubric to self-assess their performance had a better writing score and performed better than the comparison groups in terms of the seven criteria evaluated: ideas and content, organization, voice and tone, word choice, sentence fluency, conventions and paragraph formatting. The studies which have investigated the learners' perceptions about the effectiveness of rubrics in improving their writing skills (e.g., Andrade \& Du, 2005; Reynolds-Keefer, 2010) have found that "students perceived that the rubric helped them to set the task goals, to plan, to supervise their work, to reflect about feedback, to achieve better grades, to improve the quality of their work, and to be less anxious" (as cited in Panadero \& Jonsson, 2013, p. 133).

On the whole, the above journey and investigation into the role and functions of error analysis, feedback and the use of rubric reveal that they have the potentiality to make the teachers and more importantly learners aware of the effectiveness of learning process, problematic areas in the learners' performance and, as a result, informatively improve their practices.

\section{Method}

\subsection{Participants and setting}

Through convenient sampling, 34 intermediate proficiency level students (males=18 and females=16) of English Language and Literature in two intact writing classes taught by the same instructor in a state university in Iran took part in the study. These students had already passed courses on Reading Comprehension, Grammar and Conversation and had some experience of writing in English. In fact, they were in their third semester in which they had to learn the principles and practices of paragraph writing as well as different methods and conventions of paragraph development during the writing course. An experienced writing instructor and her assistant also engaged in the practice of analyzing the students' written texts, identifying the instances of errors and deficiencies in the texts produced and offered systematic written commentary and feedback for each individual student's written texts.

\subsection{Materials}

The students' in-class written texts (a total of 272 texts) on different methods of paragraph development and support during the whole semester were collected and analyzed to identify the instances of errors in their performance on different features of writing like content and 
organization, development and support, cohesion and coherence, structure, vocabulary and mechanics. In addition, the instructor's feedback and comments on these aspects of writing were examined to identify the most important issues targeted by the instructor and, hence, to develop the intended writing rubric. It is worth-mentioning that in order to provide feedback to the students on their individual drafts, the instructor and her writing assistant collected the students drafts, typed them exactly as they were written, carefully scrutinized and categorized the errors in the texts and offered some explicit and detailed formative feedback and scores, in the form of a rating scale attached to their written drafts, which informed them about the erroneous and problematic areas in their performance and provided them with some suggestions and comments to resolve those issues in the revised drafts that they were supposed to write and hand in based on the received feedback and, thus, to improve their writing.

\subsection{Design of the study}

In order to develop the intended writing rubric, the researchers employed a rather heuristic and content analytic procedure and carefully followed the following steps:

Step 1. In each classroom session, after receiving the instruction on different aspects of writing and methods of paragraph development, the student writers wrote their in-class writing tasks under the supervision and assistance of the instructor.

Step 2. The students' written texts were collected, typed as they were written and were analyzed to identify the instances of errors and other problematic issues or even the strengths in their performance on different aspects and features of writing. More specifically, the attempt was made to ensure whether the students applied the instructional points covered during the day's lesson or not.

Step 3. In order to provide systematic feedback to the students, the instructor and her assistant developed a student-friendly feedback which provided a score for different aspects of their performance and some comments regarding their problems and some feedback and suggestions for improving their writing in the revised drafts that they were required to submit as a response to feedback and hopefully their subsequent assignments. In fact, in order to provide systematic and objective scoring to the students Paulus's (1999) essay-scoring rubric was used and in order to justify the given score and to avoid unnecessary burden on the parts of students, only those aspects of writing were targeted and emphasized that the students had already received instruction in).

Step 4. A writing profile was created for the learners and the most frequent errors in their performance with regard to different features of writing and the feedback offered on those aspects were carefully analyzed and categorized.

Step 5. The first draft of the intended comprehensive and context-sensitive feedback-providing writing rubric was developed and the decisions over the scoring weight of each category were made, and finally as a future prospect 


\section{Findings and Discussion}

This section has a rather illustrative function and, by having an eye on the principles of effective feedback, attempts to show some instances of errors in different aspects of the actual texts produced by the learners and the feedback offered on those errors. As for the common errors made by L2 learners in their writings, Ferris (2006) presented the following error types: sentence structure, word choice, verb tense, noun endings (singular/plural), verb form, punctuation, articles/determiners, word form, spelling, run-ons, pronouns, subject-verb agreement, fragments, idiom, informal. However, there may be variations in the leaners' performance due to their L1 background and a variety of other individual differences variables like learners' motivation, learning styles, degree of effort, etc. (Ferris, 2011). The present study moves a step forward and takes into account the macro-level errors of leaners in the features of writing like content, organization, cohesion and coherence, etc. as well. In addition, based on the guiding principles for offering effective feedback presented by Ferris and Hedgcock (2005, as cited in Ferris, 2007, p. 168), the researchers tried to follow some relevant ones in writing the features.

\subsection{The developed writing rubric}

The (comprehensiveness of) analytic rating scales/rubrics and the reliable diagnostic information which they provide can be a good source in assisting the learners in identifying the problematic and erroneous aspects of their performance and by taking informed actions resolve those issues and, hence, improve their writing (Weigle, 2002). Many scholars (e.g., Fulcher, 2003; McNamara, 1996) believe in the dominance of an atheoretical and intuition-based view for the development of rating scales and rubrics. However, the present study, by incorporating the ideas of feedback and error analysis and more specifically by targeting the learners' individual needs in a specific learning context, attempted to develop a comprehensive and context-sensitive writing rubric. Herein some descriptions of the components of writing, some dominant and rather common errors in different aspects of students' performance in the written samples and the corresponding responsive items in the analytic rubric are presented.

\subsubsection{Content and Organization}

In AIMS Six Trait Analytic Writing Rubric Official Scoring Guide (2006) content is generally considered as the degree to which the presented ideas are clear, well-developed, complete and relevant to the topic at hand and the organization refers to the degree to which the overall structure of the paragraph/essay suits the topic and the different parts like introduction (topic sentence), conclusion and supporting details appropriately enrich the theme. In fact, here the learners are expected to provide sufficient information about the topic at hand and organize them in accordance with the established principles of writing in academic settings and ease the readers' understanding of the conveyed messages and engage their attention and interest. However, the students may face many problems in this organizational and communicative aspect of writing. For example, they may not have enough knowledge of the topic or may not be able to present and order the ideas in an effective way. Since most of the students have difficulty in starting the composition, they may not come up with an effective and focused 
topic sentence which possibly can guide the presentations of subsequent ideas. Some of the comments targeting this aspect of writing are as follow:

Table 1. Feedback for the writers' performance on content and organization

\begin{tabular}{|c|c|c|}
\hline Content and Organization & Yes & No \\
\hline \multicolumn{3}{|l|}{ The paragraph has clear introduction, body and conclusion. } \\
\hline \multicolumn{3}{|l|}{ The paragraph is well-organized and there is logical sequencing of ideas. } \\
\hline \multicolumn{3}{|l|}{$\begin{array}{l}\text { The paragraph meets allspecified requirements as to length, subject, pattern of } \\
\text { organization, etc. }\end{array}$} \\
\hline \multicolumn{3}{|l|}{$\begin{array}{l}\text { The grouping and hierarchy of presenting ideas, which shows idea importance, is } \\
\text { appropriate \& effectively handled. }\end{array}$} \\
\hline \multicolumn{3}{|l|}{$\begin{array}{l}\text { There are not much introductory sentences and the writer directly expresses the main } \\
\text { point. }\end{array}$} \\
\hline \multicolumn{3}{|l|}{ The paragraph has a focused topic sentence and includes no/few loosely related ideas. } \\
\hline \multicolumn{3}{|l|}{ The topic sentence has a controlling idea and the main point is effectively presented. } \\
\hline \multicolumn{3}{|l|}{ The topic sentence is structurally correct and explicitly and precisely stated. } \\
\hline The topic sentence is to-the-point, effective and rather interesting to the readers. & & \\
\hline \multicolumn{3}{|l|}{$\begin{array}{l}\text { The content is clearly relevant, convincing, unified and functions to add weight to the } \\
\text { writer's position. }\end{array}$} \\
\hline \multicolumn{3}{|l|}{$\begin{array}{l}\text { The content is managed effectively through grouping and/or paragraphing main ideas } \\
\text { and supporting evidence. }\end{array}$} \\
\hline \multicolumn{3}{|l|}{$\begin{array}{l}\text { A good knowledge of the topic is depicted and information is presented in a logical } \\
\text { order and maintains the interest of the audience. }\end{array}$} \\
\hline \multicolumn{3}{|l|}{ The paragraph is focused, purposeful, and reflects clear insight about ideas. } \\
\hline \multicolumn{3}{|l|}{$\begin{array}{l}\text { The concluding sentence is effective and is a logical and natural outcome of the } \\
\text { argument in the body. }\end{array}$} \\
\hline \multicolumn{3}{|l|}{ The writer's point of view is consistently the same throughout the composition. } \\
\hline $\begin{array}{llllllll}\text { Score: } 1 & & 2 & & 3 & & 4 & 5 \\
7 & 8 & & 9 & & 10 & & \end{array}$ & 6 & \\
\hline Comments: & & \\
\hline
\end{tabular}

\subsubsection{Support and Development}

In almost any textbooks about writing, there are some sections dedicated to introducing different methods of paragraph development (e.g., illustration, details, anecdotes, facts and statistics, definitions and classifications, comparison and contrast, cause and effect) and the specific features of the specific genre (Swales, 1990) and intended discourse structures (Shokouhi, 2007). Accordingly, the students are required to learn and practically apply these principles while engaged in the practice of writing their genre-specific texts in the educational settings. In fact, it is expected that the written text "represent a relevant and adequate answer to the task set with adequate detail to support the points being made" 
(Ashwell, 2000, p. 254). However, there might be some problems in the learners' development of ideas. For example, they might not be familiar with the conventions of developing ideas in a specific supporting method and come up with an unorganized paragraph in which the major and minor supporting details are haphazardly mixed. The range of supporting ideas may not be adequate for the full development of the topic sentence or they may be repetitive or have logic flaws. In order to respond to the problems in this aspect of writing, which is highly important in the communicative approaches, the instructors must plan focused instruction and provide illustrative models for the learners to make them familiar with such conventions. In subsequent stages, offering systematic feedback, like those presented in the following table, can be of great help for the learners.

Table 2. Feedback for the writers' performance on support and development

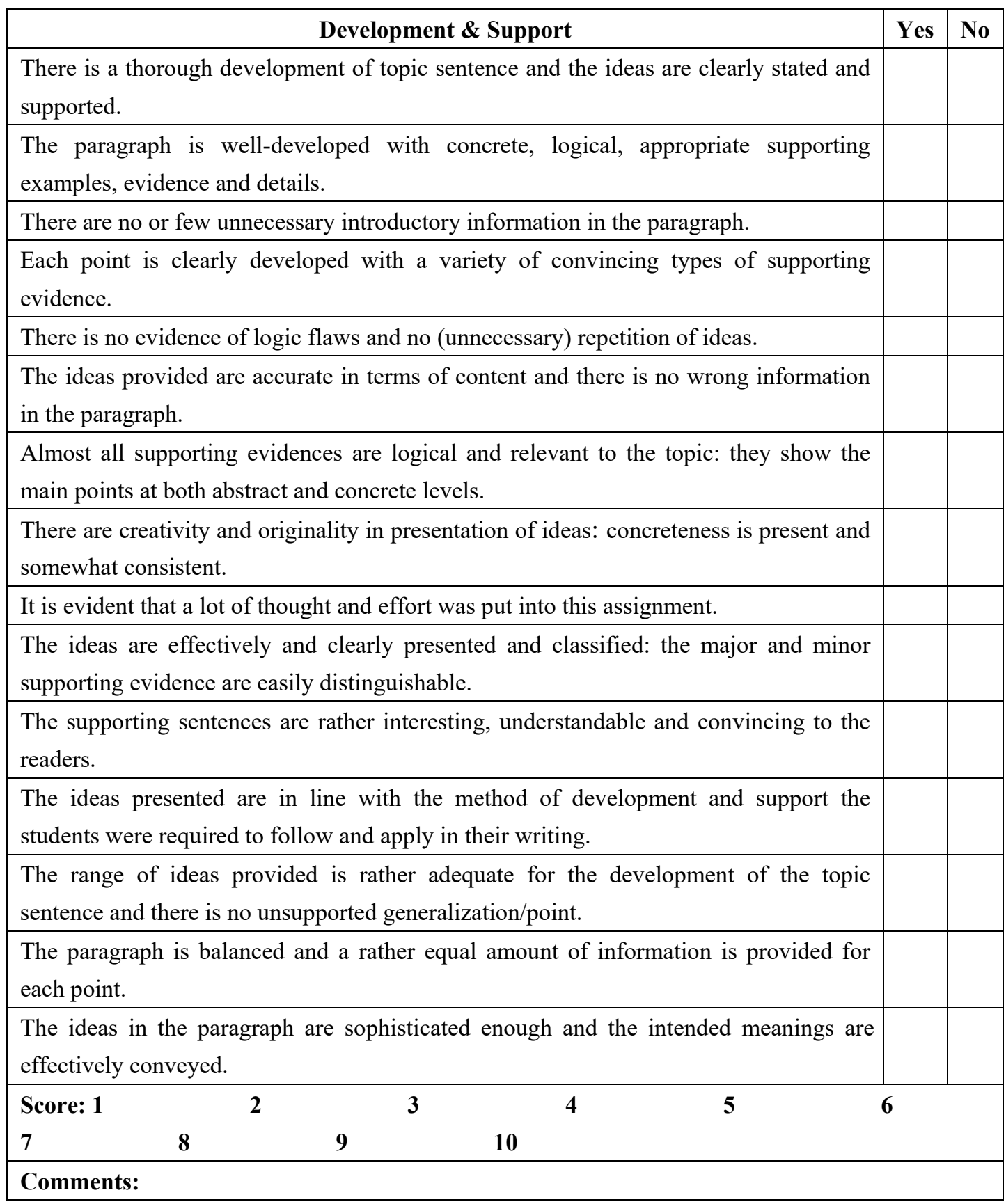




\subsubsection{Cohesion and Coherence}

Speakers and writers use internal cues which indicate how the parts of texts are related to each other. These cues create cohesion or lexical or grammatical ties which show relationships between the ideas in a text (Johnstone, 2008). The best treatment of cohesion is presented in the works by Halliday and Hassan (1976) in which they describe "five general grammatical and lexical strategies that speakers [and writers] use (and hearers [or readers] expect) for showing how the meanings of parts of different sentences are related to each other" (Johnstone, 2008, p. 118). These cohesive devices are references, substitution, ellipsis, conjunction and lexical cohesion. A closely related concept is coherence which refers to the logical connections in the text which build on semantic ties in discourse (Yule, 2010). A text can have coherence when the ideas flow smoothly and the readers' understanding of ideas and main points is not inhibited (Fowler \& Aaron, 2007). Relevance of ideas to each other and to the topic and correct use of cohesive devices help a written text to enjoy a good level of coherence. However, there are many problems in the texts produced by EFL learners in this aspect of writing. For example, the composition may not have unity and there may be some irrelevant ideas. The ideas and sentences may not be appropriately connected to each other and the range of cohesive devices used may be limited to the extent that readers' understanding of the text may be inhibited. Some beneficial feedback and commentaries on this aspect of writing are presented in the following table: 
Table 3. Feedback for the writers' performance on cohesion and coherence

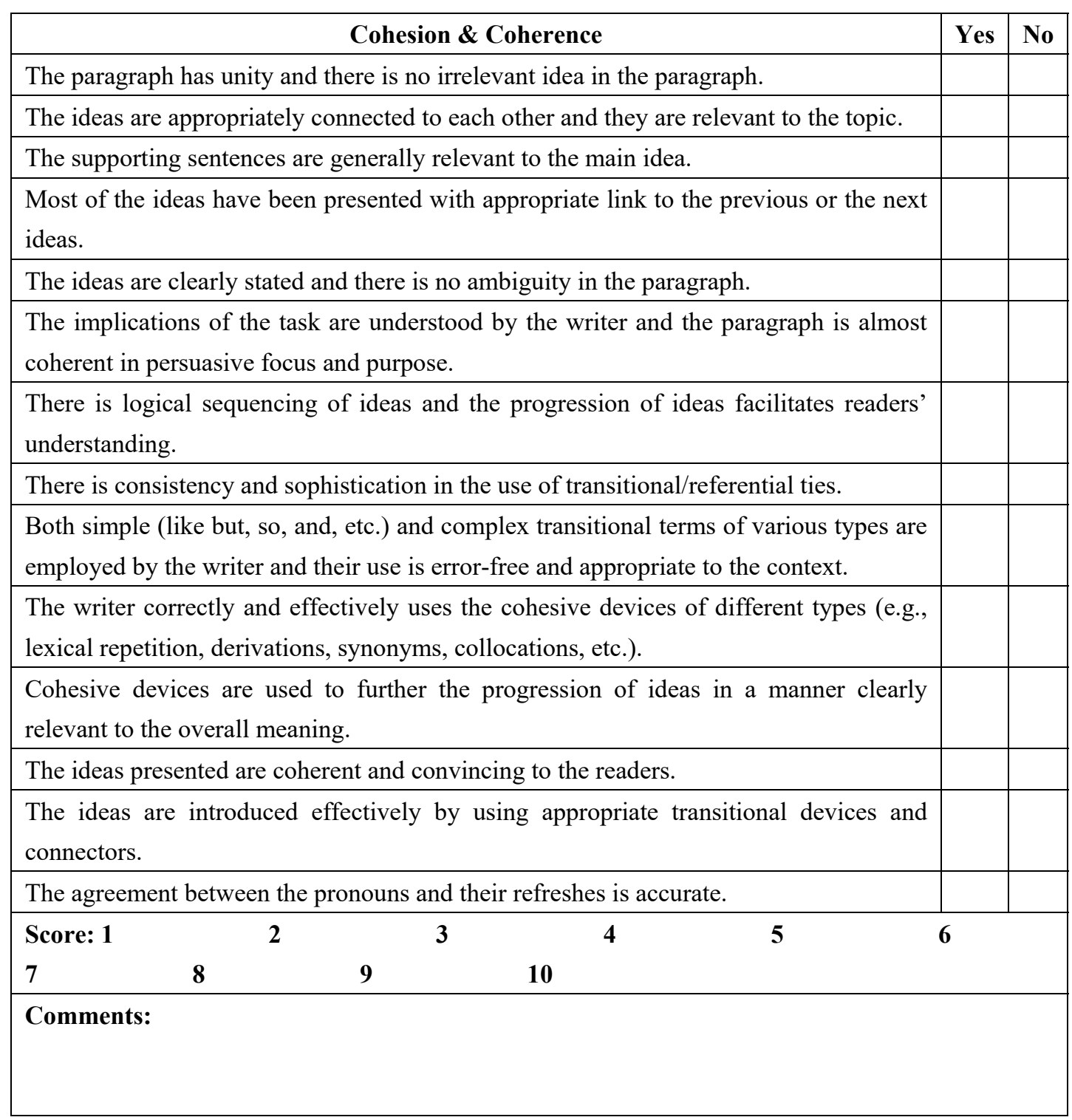

\subsubsection{Structure}

Identification and categorization of errors in this aspect of writing and provision of feedback on these issues, to the extent of ignoring the content and communicative aspect of the written text, have been the primary preoccupations of writing instructors and teachers. However, Raimes (1983) has suggested that teachers should focus on errors in structure as well as contents and focus on the linguistic features only when the ideas are developed. The structural errors can be in different aspects of the texts produced from morphological to syntactic levels. For example, the writers make errors in the choice of inflectional morphemes, word choice, verb tense, subject-verb agreement, run-on and sentence fragments, etc. (see also Ferris, 2011). It is also expected that the students use a variety of simple and complex structures like coordination and subordination, parallel structures and so on. Following comments can be used in responding to some of the errors or deficiencies in this aspect of writing. 
Table 4. Feedback for the writers' performance on structure

\begin{tabular}{|c|c|c|}
\hline Structure & Yes & No \\
\hline $\begin{array}{l}\text { There are very few or no errors of Agreement, Tense, Parts of speech, Placement, } \\
\text { Number, Gender, Word order, Articles, Pronouns and Prepositions. }\end{array}$ & & \\
\hline There are both simple and complex constructions which are mostly used accurately. & & \\
\hline $\begin{array}{l}\text { There are few errors in sentence structures, especially errors in sentence/clause } \\
\text { boundaries like run-ons, comma splices, etc. }\end{array}$ & & \\
\hline $\begin{array}{l}\text { The sentences are clear and there is no fragment (i.e., incomplete) and dangling } \\
\text { structures in the paragraph. }\end{array}$ & & \\
\hline $\begin{array}{l}\text { There is variety in sentence types and the writer has shown competence in coordination } \\
\text { and subordination. }\end{array}$ & & \\
\hline The number and type of errors made does not interfere with meaning. & & \\
\hline There is no instance of non-English patterns and structures in the paragraph. & & \\
\hline $\begin{array}{l}\text { Most of the sentences are grammatically correct and appropriate regarding the formal } \\
\text { style of writing. }\end{array}$ & & \\
\hline There are no cases of informal expressions and contractions in the text. & & \\
\hline $\begin{array}{l}\text { The word order, sequences of tenses and parallel structures are correctly and } \\
\text { appropriately handled. }\end{array}$ & & \\
\hline $\begin{array}{l}\text { The sentences are not unnecessarily lengthy and the intervening elements do no inhibit } \\
\text { the readers' understanding. }\end{array}$ & & \\
\hline $\begin{array}{lllllll}\text { Score: } 1 & & 2 & & 3 & & 4 \\
7 & 8 & & 9 & & 10 & \end{array}$ & 6 & \\
\hline Comments: & & \\
\hline
\end{tabular}

\subsubsection{Vocabulary and Meaning}

Vocabulary is considered as one of the basic components of language learning and since lexical items carry the basic information, deficiencies in this aspect of knowledge may affect learners' communication skills (Nation, 2001). It is also suggested that learners' vocabulary size and depth have important implications for their success in productive skills and lexical richness can enhance the quality of their writing (Laufer \& Nation, 1995). Research has also indicated that lack of sufficient vocabulary knowledge can be a source of impediment and can contribute to writing difficulty for foreign language learners (Santos, 1988; Astika,1993). Therefore, acceptable vocabulary knowledge can assist learners in the clear and effective communication of thoughts and ideas. According to Santos (1988), making use of wrong and imprecise words and other lexical expressions may obscures the meaning (content) of a text and results in a negative judgment and appraisal of the text and writer. Some of the feedback and comments which can be directed toward this aspect of writing are as follow. 
Table 5. Feedback for the writers' performance on vocabulary and meaning

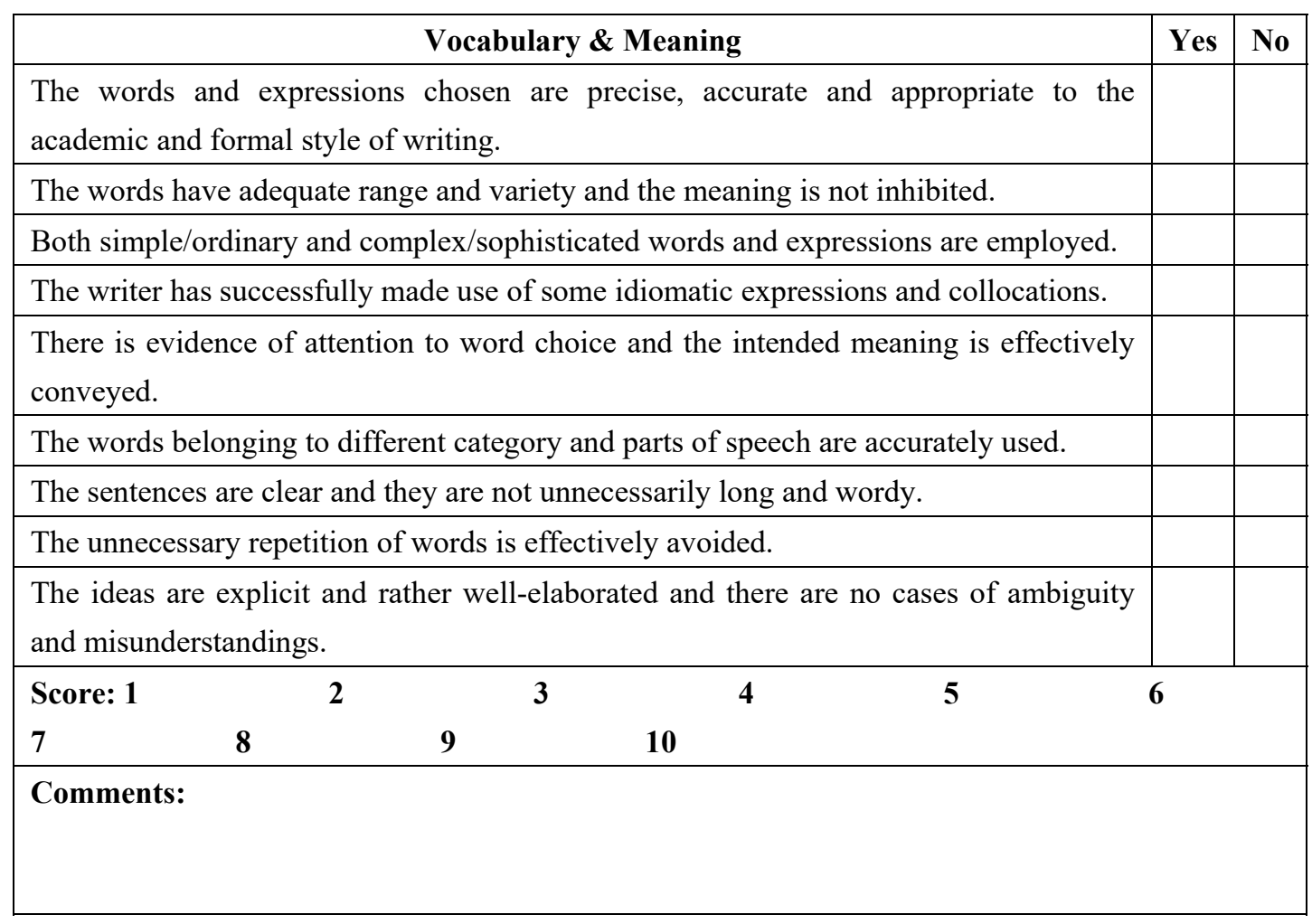

\subsubsection{Mechanics}

In order to enhance the readability of their texts, writers must have a good grasp of and use a set of standard writing conventions such as grammar, capitalization, punctuation, usage, spelling and appropriate paragraphing (Spandel \& Stiggins, 1990). Despite their importance in effectively conveying the ideas and giving a kind of face validity to the texts produced by learners, these features do not receive enough instructional focus in EFL contexts and learners are expected to develop the knowledge of these aspects of writing on their own. In fact, it is believed that "ignoring mechanics may take extra mental effort on the part of young writers, as their intentional control over mechanics and the writing process may not be sufficiently developed for this to occur effortlessly" (Scardamalia \& Bereiter, 1986, as cited in Graham, Berninger, Abbott, Abbott, \& Whitaker, 1997, p. 170). In order to respond to the possible common problems in the learners' drafts, teachers can use some of the following comments. However, before offering feedback on this aspect of writing, EFL learners, who have written in different writing conventions in their first language, need some focused instruction and practice for using these features; otherwise, we may impose on them a rather unjustified burden. 
Table 6. Feedback for the writers' performance on mechanics

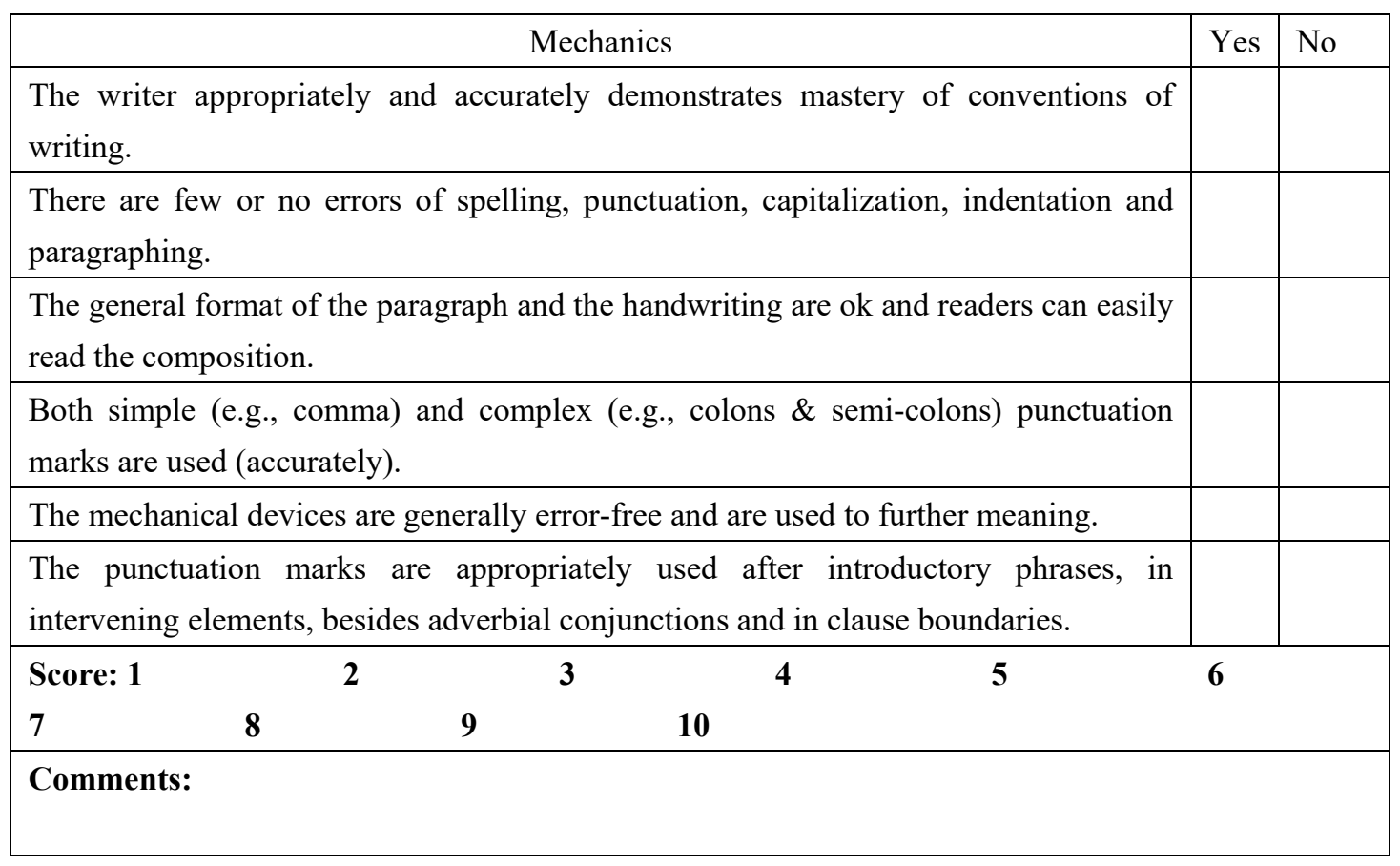

\section{Conclusion}

Inasmuch as errors are an inevitable part of the learners' performance while engaging in the act of writing, teachers must adopt systematic procedures to respond to these deficiencies. However, Zamel (1985) in her exploration of the comments offered by ESL teachers on the students' drafts claimed that teachers 'frequently 'misread' students' texts, are inconsistent in their reactions, make arbitrary corrections, provide vague prescriptions, impose abstract rules and standards, respond to texts as fixed and final products, and rarely make content-specific comments or offer strategies for revising the text" (p. 79). In addition, as Ferris (2007) comments, responding to the students' writing is one of the most challenging and time-consuming aspects of writing instructors' job. Accordingly, as it was mentioned, the present study attempted to develop a rather comprehensive, flexible and context-sensitive writing rubric to respond to these challenges and to offer critical instructional opportunities for both learners and teachers (Ferris, 2003). This instrument can hopefully supplement other effective instructional practices, such as focused instruction on grammar, different methods of paragraph support and development of ideas and English writing conventions or even instruction on vocabulary and doing extensive reading, to improve EFL students' writing. In fact, the writing instructors can make selective use of the comments offered in this rubric, but the important point is that they must encourage their learners to reflect and act upon the feedback received and require them to revise their written textsbased on the feedback received and try to improve their writing ability.

\section{References}

AIMS Six Trait Analytic Writing Rubric Official Scoring Guide (2006). US Arizona Department of Education. 
Andrade, H. G. (2001). The effects of instructional rubrics on learning to write. Current issues in education, 4(4), 1-28.

Andrade, H. G., \& Boulay, B. A. (2003). Role of rubric-referenced self-assessment in learning to write. The Journal of Educational Research, 97(1), 21-30. http://dx.doi.org/10.1080/00220670309596625

Andrade, H. L., Du, Y., \& Wang, X. (2008). Putting rubrics to the test: The effect of a model, criteria generation, and rubric-referenced self-assessment on elementary school students' writing. Educational Measurement: Issues and Practice, 27(2), 3-13. http://dx.doi.org/10.1111/j.1745-3992.2008.00118.x

Andrade, H., \& Du, Y. (2005). Student perspectives on rubric-referenced assessment. Practical Assessment, Research \& Evaluation, 10(3), 1-11.

Andrade, H., Du, Y., \& Mycek, K. (2010). Rubric-referenced self-assessment and middle school students' writing. Assessment in Education: Principles, Policy \& Practice, 17(2), 199-214. http://dx.doi.org/10.1080/09695941003696172

Andrade, H., Wang, X. L., Du, Y., \& Akawi, R. L. (2009). Rubric-referenced self-assessment and self-efficacy for writing. Journal of Educational Research, 102(4), 287-301. http://dx.doi.org/10.3200/JOER.102.4.287-302

Arter, J., \& McTighe, J. (2001). Scoring rubrics in the classroom. Thousand Oaks: Corwin Press Inc.

Ashwell, T. (2000). Patterns of teacher response to student writing in a multiple-draft composition classroom: Is content feedback followed by form feedback the best method?. Journal of Second Language Writing, 9(3), 227-257. http://dx.doi.org/10.1016/S1060-3743(00)00027-8

Astika, G. G. (1993). Analytical assessments of foreign students' writing. RELC Journal, 24(1), 61-70. http://dx.doi.org/10.1177/003368829302400104

Bitchener, J., \& Knoch, U. (2008). The value of written corrective feedback for migrant and international students. Language Teaching Research, 12(3), 409-431. http://dx.doi.org/10.1177/1362168808089924

Brown, G. T. L., Glasswell, K., \& Harland, D. (2004). Accuracy in the scoring of writing: Studies of reliability and validity using a New Zealand writing assessment system. Assessing Writing, 9(2), 105-121. http://dx.doi.org/10.1016/j.asw.2004.07.001

Brown, H. D. (2007). Principles of language learning and teaching (5th ed.). New York: Pearson Education.

Chandler, J., (2003). The efficacy of various kinds of error feedback for improvement in the accuracy and fluency of L2 student writing. Journal of Second Language Writing 12, 267-296. http://dx.doi.org/10.1016/S1060-3743(03)00038-9 
Corder, P. (1967). The significance of learner errors. International Review of Applied Linguistics 5(4), 161-169.

Corder, S. P. (1971). Idiosyncratic dialects and error analysis. International Review of Applied Linguistics, 9 (2), 147-160. http://dx.doi.org/10.1515/iral.1971.9.2.147

Dulay, H. C., Burt, M. K., \& Krashen, S. D. (1982). Language two. Oxford University Press.

Ellis, R., Barkhuizen, G. (2005). Analyzing learner language. Oxford University Press, Oxford.

Elwood, J. A., \& Bode, J. (2014). Student preferences vis-à-vis teacher feedback in university EFL writing classes in Japan. System, 42, 333-343. http://dx.doi.org/10.1016/j.system.2013.12.023

Fang, Z., \& Wang, Z. (2011). Beyond rubrics: Using functional language analysis to evaluate student writing. Australian Journal of Language and Literacy, 34(2), 147-165.

Ferris, D. (2007). Preparing teachers to respond to student writing. Journal of Second Language Writing, 16(3), 165-193. http://dx.doi.org/10.1016/j.jslw.2007.07.003

Ferris, D. (2011). Treatment of error in second language student writing. University of Michigan Press.

Ferris, D. R. (2002). Treatment of error in second language student writing. Ann Arbor, Michigan: University of Michigan Press.

Ferris, D. R. (2003). Response to student writing: Research implications for second language students. Mahwah, NJ: Erlbaum.

Ferris, D. R. (2014). Responding to student writing: Teachers' philosophies and practices. Assessing Writing, 19, 6-23. http://dx.doi.org/10.1016/j.asw.2013.09.004

Ferris, D., \& Roberts, B. (2001). Error feedback in L2 writing classes: How explicit does it need to be? Journal of Second Language Writing, 10, 161-184.

Fowler, H. R., \& Aaron, J. E. (2007). The little, brown handbook. Pearson Longman.

Fulcher, G. (2003). Testing second language speaking. London: Pearson Longman.

Gass, S. \& Selinker, L. (2001). Second language acquisition: An introductory course. Mahwah, NJ: Lawrence Erlbaum.

Graham, S., Berninger, V. W., Abbott, R. D., Abbott, S. P., \& Whitaker, D. (1997). Role of mechanics in composing of elementary school students: A new methodological approach. $\begin{array}{lllll}\text { Journal of } & \text { Educational } & \text { Psychology, } & \text { 89(1), } & 170 .\end{array}$ http://dx.doi.org/10.1037/0022-0663.89.1.170

Halliday, M. K, and Hasan, R. (1976). Cohesion in English. London: Longman.

Hyland, F. (2010). Future directions in feedback on second language writing: Overview and research agenda. International Journal of English Studies, 10(2), 173-182. 
Hyland, K., \& Hyland, F. (Eds), (2006). Feedback in second language writing: Contexts and issues. New York: Cambridge University Press. http://dx.doi.org/10.1017/CBO9781139524742

Johnstone, B. (2008). Discourse analysis ( $2^{\text {nd }}$ ed.). Malden, MA: Blackwell.

Jonsson, A., \& Svingby, G. (2007). The use of scoring rubrics: Reliability, validity and educational consequences. Educational Research Review, 2, 130-144. http://dx.doi.org/10.1016/j.edurev.2007.05.002

Krashen, S. D. (1982). Principles and practices in second language acquisition. Oxford: Pergamon Press.

Kubota, M., (2001). Error correction strategies used by learners of Japanese when revising a writing task. System, 29, 467-480. http://dx.doi.org/10.1016/S0346-251X(01)00026-4

Larsen-Freeman, D. (2003). Teaching language: From grammar to grammaring. Boston: Heinle/ Thomson.

Laufer, B., \& Nation, P. (1995). Vocabulary size and use: Lexical richness in L2 written production. Applied linguistics, 16(3), 307-322. http://dx.doi.org/10.1093/applin/16.3.307

Lee, I. (2003). L2 writing teachers' perspectives, practices and problems regarding error feedback. Assessing Writing, 8, 216-237. http://dx.doi.org/10.1016/j.asw.2003.08.002

Long, M., \& Richards, J. (2006). Preface in K. Hyland \& F. Hyland (Eds), (P. XIII). Feedback in second language writing: Contexts and issues. New York: Cambridge University Press. http://dx.doi.org/10.1016/j.polymer.2006.03.051

McNamara, T. (1996). Measuring second language performance. London \& New York: Longman.

Myles, J. (2002). Second language writing and research: The writing process and error analysis in student texts. TESL-EJ, 6(2), 1-20.

Nation, I. S. (2001). Learning vocabulary in another language. Ernst Klett Sprachen. http://dx.doi.org/10.1017/cbo9781139524759

Panadero, E., \& Jonsson, A. (2013). The use of scoring rubrics for formative assessment purposes revisited: A review. Educational Research Review, 9, 129-144. http://dx.doi.org/10.1016/j.edurev.2013.01.002

Parr, M. J., \& Timpersely, S. H. (2010). Feedback to writing, assessment for teaching and learning and students progress. Assessing Writing, 15, 68-85. http://dx.doi.org/10.1016/j.asw.2010.05.004

Paulus, T. M. (1999). The effect of peer and teacher feedback on student writing. Journal of Second Language Writing, 8, 265-289. http://dx.doi.org/10.1016/S1060-3743(99)80117-9

Perlman, C. C. (2003). Performance assessment: Designing appropriate performance tasks and scoring rubrics. North Carolina, USA. 


\section{Macrothink}

Journal of Studies in Education

ISSN 2162-6952

2015, Vol. 5, No. 4

Raimes, A. (1983). Techniques in teaching writing. New York: Oxford University Press.

Reynolds-Keefer, L. (2010). Rubric-referenced assessment in teacher preparation: An opportunity to learn by using. Practical Assessment Research \& Evaluation, 15(8). Retrieved from http://pareonline.net/getvn.asp? $\mathrm{v}=15 \& \mathrm{n}=8$.

Rezaei, A. R., \& Lovorn, M. (2010). Reliability and validity of rubrics for assessment through writing. Assessing writing, 15(1), 18-39. http://dx.doi.org/10.1016/j.asw.2010.01.003

Richards, J. C. \& Schmidt, R. (2002). Longman dictionary of language teaching and applied linguistics. Pearson Education Limited.

Santos, T. (1988). Professors' reactions to the academic writing of non-native speaking students. TESOL Quarterly, 22, 69-88. http://dx.doi.org/10.2307/3587062

Selinker, L. (1972). Interlanguage. International Review of Applied Linguistics, 10(3), 209-231. http://dx.doi.org/10.1515/iral.1972.10.1-4.209

Shokouhi, H. (2007). A functional analysis of rhetorical organization of recognition and production tasks by EFL learners. Odense Working Papers in Language and Communication, 34, 717-734.

Silvestri, L., \& Oescher, J. (2006). Using rubrics to increase the reliability of assessment in health classes. International Electronic Journal of Health Education, 9, 25-30.

Spandel, V., \& Stiggins, R. J. (1990). Creating writers: Linking assessment and writing instruction. Longman Publishing Group.

Sundeen, T. H. (2014). Instructional rubrics: Effects of presentation options on writing quality. Assessing Writing, 21, 74-88. http://dx.doi.org/10.1016/j.asw.2014.03.003

Swales, J. M. (1990). Genre analysis: English in academic and research settings. Cambridge: Cambridge University.

Weigle, S. C. (2002). Assessing writing. Cambridge, UK: Cambridge University Press. http://dx.doi.org/10.1017/CBO9780511732997

Yule, G. (2010). The study of language. Cambridge University Press. http://dx.doi.org/10.1017/cbo9780511757754

Zamel, V. (1985). Responding to student writing. TESOL Quarterly, 19(1), 79-101. http://dx.doi.org/10.2307/3586773 